\title{
Locarno 2005
}

\author{
By Ron Holloway
}

Fall 2005 Issue of KINEMA

\section{WIM WENDERS IN LOCARNO AND BUTTE}

"The cinema has replaced the church" - ran the headline atop an interview with Wim Wenders in the Zürcher Tages-Anzeiger on the second day of the $58^{\text {th }}$ Locarno International Film Festival (3-13 August 2005). Although this flip phrase was part of a rather innocuous dialogue with the German cult director about himself and his film career, Wenders felt obliged nonetheless to excuse himself before a large ecumenical gathering on the occasion of Interfilm's $50^{\text {th }}$ anniversary. Besides, he was about to be handed the Interfilm Honorary Award for his achievements as a film director. "That headline was not my idea," he said. And added: "I felt especially honoured in the laudatio when my work was compared to that of the German philosopher Walter Benjamin." Queried as to whether "cinema has really replaced the church," Wenders could only smile. Every cineaste in the room knew that this same phrase had been used in the past by such illustrious filmmakers as Renoir, Buñuel, and Eisenstein, albeit for different reasons.

That same evening, Wim Wenders was honoured by Locarno festival director Irene Bignardi with an Honorary Lifetime Achievement Leopard, with German Chancellor Gerhard Schroeder present for the award ceremony. "Why for a lifetime?" Wenders asked in an interview. "I don't think I am about to close the book." Even though his sixtieth birthday was just around the corner, he didn't feel this was a ripe old age for a film director. And, of course, he was right. After all, Ingmar Bergman was shooting Fanny and Alexander at sixty. And, at seventy, Luis Buñuel was honoured with an Oscar for The Discrete Charm of the Bourgeoisie. Given these singular achievements as a yardstick, a lifetime achievement award at sixty did seem a bit too premature. And given that Wim Wenders ranks among Europe's leading film directors, he may well be in the twilight of a remarkable career as writer, director, documentarist, and president of the European Film Academy.

Don't Come Knocking, the $37^{\text {th }}$ film by Wim Wenders, was presented on the Piazza Grande in Locarno before a sellout audience of 7000. Just before the screening, Wim, in typical Wenders style, flashed his Locarno Leopard T-shirt. Premiered in Cannes, where the film was treated in Le Monde as a possible Golden Palm winner, Don't Come Knocking was bypassed for any award by the international jury under Emir Kusturica. Now, with the German premiere in the offing, the film might just breathe new life. For at the end of August it will premiere in Germany under the aegis of American distributor UIP. Shot mostly in Moab, Utah ("John Ford Country") and in Butte, Montana (the site of Dashiell Hammett's hard-boiled Red Harvest, published in 1929), the latter site is by far the most interesting element in the film.

Don't Come Knocking is the story of an aging Western hero. Howard Spence, played by playwright Sam Shepard, who collaborated with Wim Wenders on Paris, Texas (Golden Palm 1984, camera Robby Müller), hightails it away from the Moab location set for his latest Western - right in the middle of a love scene. The heavy-drinking, drug-addicted womanizer has reached the end of his rope. As a cowboy hero Howard Spence is burnt out - and he knows it. However, since the film has to be finished, a "Completion Bond Bounty Hunter" (Tim Roth) sets off on his trail, which leads first to Las Vegas, where his mother lives - Eva Maria Saint in a neat cameo. Howard Spence has only stopped there long enough to discover, via a postcard sent to his mother, that he may have a son waiting for him in Butte, Montana. As it turns out, Doreen (Jessica Lange), one of his long-lost girlfriends, is there as well. So, too, is a miss carrying an urn with the ashes of her mother, who had also had a child-bearing liaison with Spence.

Apparently, Wim Wenders - like Dashiell Hammett and Jack Kerouac before him - has fallen in love with Butte, once the copper-ore capital of America. Well over a hundred years ago, when copper was discovered in the Montana gulches. Butte for a while was one of the most important cities in the States. The discovery of a rich vein of copper in the region led to the "War of the Copper Kings" and the founding of the all-powerful Anaconda Copper Company. "Montana people drink too much, fight too much, love too much," wrote Jack Kerouac of On the Road fame in a special report he had written for Esquire magazine. Back in the 1920s, 
when Prohibition was in vogue, the erstwhile detective and would-be writer Dashiell Hammett arrived in this "paradise" of heavy drinking, wild gambling, and easy-going prostitution. That's when he wrote his first novel, Red Harvest, about the red gold in the Butte copper mines. Many critics consider it his masterpiece.

Back in 1980, when I met Wim Wenders in San Francisco, he was preparing to shoot Hammett (released 1982) for the Zoetrope Studio headed by Francis Ford Coppola in California. During a lull in the production, due to a financial glitch, Wim took the time to travel to Butte and do a bit of location scouting on his own. According to Tom Luddy, his Zoetrope contact and cofounder of the legendary Telluride Film Festival (where Wim is a regular guest), Wenders was considering the possibility of shooting some location scenes in Butte for the Hammett project, an idea that eventually came to naught. But Wim never dropped the idea entirely. The entire second half of Don't Come Knocking was shot in Butte - bathed in sparkling Edward Hopper imagery (cameraman Frank Lustig). Viewed from this angle, you can forget the chatter that Don't Come Knocking is a sequel to Paris, Texas. Rather, Don't Come Knocking is the continuation of the Hammett saga. Better: the third part of a personal "Western trilogy" by cult director Wim Wenders. As to how the film will fare with the America public at Telluride on the Labour Day weekend in September, that's another question altogether. Unfortunately, Sam Shepard is not as good an actor as he is a dramatist.

\section{Author Information}

Ron HOLLOWAY (1933-2009) was an American critic, film historian, filmmaker and correspondent who adopted Europe as his home in the early fifties and spent much of his life in Berlin. He was an expert on the study of German cinema and against all odds produced, with his wife Dorothea, the journal German Film, keeping us up-to-date with the work of directors, producers and writers and the showing of German films around the world.

In 2007, Ron Holloway and his wife were awarded the Berlinale Camera Award. Ron also received the Bundesverdienstkreuz (German Cross of Merit), Polish Rings, Cannes Gold Medaille, the American Cinema Foundation Award, the Diploma for Support of Russian Cinema and an honorary award from the German Film Critics' Association.

Ron was also a valued contributor to Kinema for the past fifteen years. 